\author{
Jarosław Piątek \\ University of Szczecin (Poland)
}

\title{
Is the Modernization Process Becoming a Challenge or a Threat to the Security Policy and the Armed Forces?
}

\begin{abstract}
In spite of defining the role of various measures of security policy implementation the weight of one has been quite unequivocally assessed for the current policy. The main position for contemporary Poland is to be taken by the armed forces.

Under these conditions, the Polish Army has become a basic element of the defense system of Poland not only in terms of image. It is not surprising then that currently the armed forces have received a wide range of tasks regarding security - both internal and external. President Duda and the government of Law and Justice proudly show the 2 percent of GDP spent on defense and an even higher target, at the latest in 2030. However, this does not create a perspective that would allow "hurray" optimism. The key to describing the Armed Forces of the Republic of Poland seems to be their ability to respond to the revolution in the field of military and the ability to modernize.

Despite the plans of the Ministry of National Defense and declarations given in media, this process faces a number of difficulties. Not only do we create "abstract" visions of needs for the current policy, but we also offend our partners and those that are still our allies.

The arms policy, so important from the point of view of this "self-sufficiency", was brought to the accusations of lobbying, corruption, and fraud; not only do we not pay attention to our own needs, but we also create innovative concepts for the current policy that cause us to wander in dilettantism.

It seems that the shape of the implementation of the modernization of the Armed Forces is affected not only by the current policy. To a large extent, the condition of the Polish arms industry is also a decisive factor in the absorption of modernization.
\end{abstract}

Keywords: Armed forces, security policy, the Polish Army, threats, challenges, armed forces modernization 


\section{The Place of Technology in the Military of the Beginning of the 20-th Century}

The development of technology, the introduction of new technologies to the army and the consideration of their military decision-makers may seem to be an uncomplicated term in descriptions. However, only seemingly. Disputes can affect many aspects. There are different ways of presenting the typical path of using technologies in the army and of answering the question of why some of them reach it while others do not. The adaptation of the army to the development of technology does not run its course in an uniform manner: some technologies and methods of action have taken root there for a long time, while others have quickly lost their value and have been discarded. The view is further complicated by the dominant, yet not shared by everyone, belief that many contemporary armed forces have begun a perceived revolution in military matters (Piątek, 2012, pp. 93-172). Many believe that a quality-wise new situation has been created, in which the application of many new technologies constitutes a fundamental breakthrough in the way of preparing and conducting potential combat operations. Their basis is to abandon the concept of air-land combat dominant since the 1980s (Doughty, 2001,pp.46-50) in favor of a new blitzkrieg form, which involves paralyzing the enemy's ability to use information and thus crushing his ability to assess the situation and command.

The main drive of change in this area is the American military policy and its military revolution programme implemented since 1989 (Blaker, 1997, pp. 46-50; Colin, 2004, pp. 27-59; Piątek, 2011, pp. 832-833). Its main assumptions, the so-called Joint Visions for 2010-2020, provide for the improvement of precision, speed and military firepower. The aim of the conducted revolution is to increase the relative advantage of US forces through the possibility of conducting precise combat operations supported by functional logistics with full-scale protection. Precise weapons in combination with information technology are to be a means to this end. The greatest RMA enthusiasts say that these measures will bring about a breakthrough in terms of the army's access to information, deeply transforming the nature of the armed forces and the war itself.

\section{Polish Army in the Security Policy}

The currently implemented state security policy is based on calculations related to the recognition of the Atlantic option as the basic foundation of military security for Poland. NATO has been recognized as the most important security institution, while the European Union, the OSCE, the Council of Europe and sub-regional groupings are assumed to play a complementary role and support the strengthening of security with political, economic and other means (Zięba, 2011). In the current political situation, the Polish authorities do not hide their skepticism towards all European plans to "become independent" from NATO and the USA. However, this approach is nothing new (Zięba, 2007, p. 387). In order 
to pursue vital interests, in consequence, cooperation with the US was favored because it is in a close alliance with this country that they see for themselves a guarantee of military security. In the current and strategic perspective, NATO and the alliance with the USA are to constitute a guarantee of military security. According to the politicians of the ruling party in Poland, the NATO alliance is currently the only functioning and effective security system in the world. According to these politicians, Poland has a specific structure, means and experience in order to be present in the structures and seek the ability to strengthen its position. These activities are aimed at minimizing threats, preventing conflicts, developing cooperation, and thus stabilizing the international environment of Poland both in the regional and global dimensions. The formulated priorities of Poland's foreign and security policy are a derivative of the outlined vision for the development of Poland's future relations on the international arena. It is in this dimension that the current ruling camp understands the implementation of tasks within the NATO alliance mainly through the deepening of Polish-American cooperation in the field of the defense system (Strategia Polskiej... 2017, p. 8, Strategia Bezpieczeństwa... 2014, p. 9).

In spite of defining the role of various measures of security policy implementation the weight of one has been quite unequivocally assessed for the current policy. The country's armed forces are to take the main position for contemporary Poland. For the above political choices, the Armed Forces of the Republic of Poland are undoubtedly one of the determinants of the strength and position of the state in the international environment. According to the rulers, a military (army) measure invariably determines the possibilities of implementing state policy (Balcerowicz, 1999, p. 21).

Under these conditions, the Polish Army has become a basic element of the defense system of Poland not only in terms of image. It is not surprising then that currently the armed forces have received a wide range of tasks as regards security - both internal and external.

It was recognized that their main task was to fight off any military aggression using all available means. The main role was attributed to the operational forces, while they are to be actively supported by the Territorial Defense Forces (Paszyn, Kordowski, Zalewski, 2016). If it is not possible for the Polish Army to conduct regular operations, it is supposed to move to other forms of combat, including partisan activities in the areas occupied by the enemy (Mrówka, 2017). A possibility to use the army in the event of natural disasters and catastrophes is also assumed.

There should arise a question in this part of our reflections about how well the Armed Forces of the Republic of Poland are prepared for the challenges arising, e.g. from RMA. Another doubt involves the "uncritical" or even "blind" trust in the possibility of strategic tying of security, including military one, with the United States. Under these conditions, it seems extremely important that the evolution of the army proceeds in a way that guarantees the place and role of the Armed Forces of the Republic of Poland in the architecture of the security of the Polish state, but also that it could equal with the armed forces of the 
United States. It should be remembered that the armed forces should ensure: protection of independence and indivisibility of the territory of Poland; security and inviolability of borders; supporting foreign policy and vital state interests on the international arena; assistance to public administration bodies in responding to non-military threats; support for anti-terrorist and rescue operations. For this purpose, the Armed Forces of the Republic of Poland should, after all, keep at the ready the necessary potential of military means to counteract or eliminate the causes and effects of external and internal threats to state security. The Polish Armed Forces must also have the ability to separate a specific potential into the integrated military structure resulting from the alliance guarantees. It seems that these activities should be in line with the state's political declarations. Unfortunately, these are largely undermined by the careless and unstable attitudes of decision-makers. This is why very often implementers of concepts both interesting and entertaining speak up. Mr. Gryglas MP quite seriously claims that the hussars are not a completely outdated formation and the Polish army should look for its worthy successors (Najnowszy pomysł..., 2018). An example of these is the existing form of development of the Armed Forces of the Republic of Poland. The adopted and promoted concept of the expansion of territorial troops at the expense of operational forces may amuse and irritate at the same time. Due to the nature of the planned activities and the organizational structure, the Armed Forces of the Republic of Poland are still divided into operational and Territorial Defense Forces with a focus on the former. However, this is no longer of strategic importance. The Polish Armed Forces have lost their operational character. The Territorial Defense Forces, which have also become a separate type of the Armed Forces, are being created now. It is planned that they will include 53 thousand soldiers (Struktura i zadania). At this point, let us note the quantitative state of other, so far considered as dominant, types of the armed forces: land forces - approx. 57 thousand soldiers (2017), air force - approx. 17.5 thousand soldiers (2017), navy - approx. 8.5 thousand soldiers (2017) and special forces - about 2.5 thousand soldiers (Możliwości militarne... 2017). Reflecting on the nature of the transformation of the technological structure of the Armed Forces of the Republic of Poland, one should ask, among others, whether this is a quantitative or qualitative change.

\section{Addressing the Threats to Poland's Security Goes Beyond the Current Policy}

Also, it seems important for the subject matter of the paper that the threats for contemporary countries do not only come from their external environment, but also from internal conditions that allow the state to fulfill its basic functions as a part of its security policy. Finally, threats call for the need to formulate responses and to take appropriate action. According to the politicians of the ruling party, Poland cannot afford to move away from the USA. In their opinion, the world map pulsates with military threats for Poland (Macierewicz w Kanadzie...2017). What is going to happen? Are we on the brink of war? Formally, every- 
thing is in perfect order. The propaganda slogans of the government, of course, do not reflect all the complicated reality, but propaganda - this time the failures, not success - is also done by the opposition. The army and state security structures are undergoing dynamic changes, but are they all going in the wrong direction? Is territorial defense indeed a "private army"? Will the construction of district shooting ranges threaten with shootings? Will tanks in the east of the country deter anyone? It all asks for a discussion with arguments, not slogans. It is indisputable that NATO and the USA finally have "their feet on Poland's ground", and 2018 will be the beginning of the functioning of the most important allied defense investment - the base of the anti-missile system in Redzikowo (Dzień otwarty...2017). Several last governments fought for this installation. President Duda and the government of Law and Justice proudly show the 2 percent of GDP spent on defense and an even higher target, at the latest in 2030. However, this does not create a perspective that would allow "hurray" optimism. We should not be deluding ourselves that distancing ourselves from European structures and indulging in the vision of defensive self-sufficiency will increase our security. Geopolitical turmoil which may threaten Poland left without allies on its own wish is not being noticed by the ruling circles.

The shortcomings of the Polish security policy result not only from the lack of a global perspective. It is no better with its immediate surroundings. Over the past years, we have not been noticing the consequences of the lack of our activity towards Ukraine. The Russian intervention in Ukraine only launched a Russophobia deepening in Poland for years, which is a seed of other ones, from Germanophobia, to Francophobia, to hostility to everything we do not "accept". As a result, the problems of the world around us are almost irrelevant to the rulers and to a large part of the society. The view that if we are with the USA we are safe prevails in the politically correct media circulation. However, is nothing a threat to us? Are we not losing the ability to assess the importance of international security in our national security policy? Only politicians with a limited horizon can claim that there is no connection between the strategic position of the country and the policy and external relations it carries out.

Building faith in defensive self-sufficiency, we distance ourselves more and more from Europe. As a consequence, our mistakes can cost us a lot. No need to look far for evidence. Without looking at strategic consequences, a "war for the army" has begun between the two constitutional centers of power. The defense of the state for the first time in decades has become a field of political struggle, where pseudo patriots play out in the name of "ideological purity" without regard to the consequences.

\section{The Effectiveness of a Security Policy is Determined by Noticing Its Challenges}

The phenomena resulting from the analysis of threats pose a challenge to security and the policy implemented for it. The challenges are, therefore, difficult tasks, new situa- 
tions forcing the need to develop effective policies and actions (Leksykon Bezpieczeństwa Wewnętrznego... pp. 746-747). From the perspective of emerging challenges, it does not matter greatly if one or the other party is in power. However, it does matter how this party uses power. Let us review the challenges for Poland's security policy, considering the threats to it, signaled before. I would include the following in those that will largely determine the effectiveness: strengthening international cooperation, finalizing tenders worth billions, rebuilding the reserves of the Polish Army, implementing the Strategic Defense Review and structural changes for the modernization of the armed forces.

The ability to cooperate internationally will greatly stimulate the security policy and, of course, within its framework, the Armed Forces of the Republic of Poland. Against this background, it seems that the implementation of NATO summits in Wales in 2014 and in Warsaw in 2016 will be crucial. One cannot also forget about preparing for the summit of the Alliance in Brussels (The article was finished before it started). This is because further decisions essential for the security of the eastern flank and Poland may be taken there (Czaputowicz: Szczyt NATO...2018). Next year the anti-missile defense system in Redzikowo will be ready, which may be an opportunity to further expand cooperation with the USA, and cooperation within the European Union will be no less important. This should be translated for the Polish Army into a number of specific actions, and will result primarily from the transfer from the level of the decision to the level of implementation. The implementation of joint exercises and further involvement in NATO Response Force, the so-called spearhead force, need to be recognized as of key importance. The deepening of international cooperation will also entail the preparation and subsequent deployment of alliance combat units in the territory of Poland. This will concern, among others, the NATO battalion battle group which is an element of the North Atlantic Treaty Organization's command system as well as gradually reinforced (e.g. with division level command, moved to Poznań) American troops, directly subordinate to US Army Europe. We must also still be ready to act for the benefit of others as part of the understanding of international cooperation. It is worth recalling Lithuania's appeal to strengthen air defense in the Baltic Sea region (Baltic Air Policing ... 2017). Polish soldiers also take part in foreign missions, including in Latvia (within the "Canadian" NATO battalion group), Romania, Afghanistan and the Middle East. Finally, according to recent decisions, defense cooperation within the structures of the European Union should be extended (Współpraca obronna... 2018).

Another aspect that can be used to strengthen international cooperation for the quality and modernization of the Polish Army is the conclusions that we should draw from the Zapad maneuvers. The proposal to transform the Multinational North-East Corps Command into an army level command is a novum in Polish action. However, the main task for the effectiveness of international cooperation should be the ability to transfer it to the lowest levels of command and military action. The Americans confirmed last year that the Army Prepositioned Stock equipment base would be built in Powidz. Preparations are also underway for the deployment of new US Army units in Europe, including artillery brigades 
and short-range counter-air defense subunits. Depending on the decision of the president and Congress regarding financing, further steps in this direction are not excluded, the more so that the law "authorizing" defense expenditures for fiscal year 2018 includes, for example, provisions on strengthening Europe's defense against cruise missiles attacks.

Equally important for the security policy of the Republic of Poland is taking steps to restore the reserves system, neglected after moving to the professional army. It is worth remembering that currently the army relies heavily on reservists trained in the times of universal conscription, and they take part in exercises more and more often. Training volunteers as part of the preparatory service allows only to partially supplement the shortage, approximately 10 to 12 thousand soldiers per year are to take part in such training sessions. The army needs to train 30-35 thousand reservists annually. The challenge for the Ministry of National Defense is to implement and combine these resources into one coherent system, as well as to develop cooperation mechanisms of the Territorial Defense Forces with operational forces. The next steps in this direction may be the creation of the Academic Legion, under which even more than 20,000 students may eventually undergo volunteer training annually, as well as training uniformed classes, which can give another few thousand trained. Will the defense department meet these challenges?

The implementation of the Strategic Defense Review is another important task in the area of state security that the Ministry of National Defense and the Armed Forces of the Republic of Poland faces. It is assumed to be the first in years planning document outlining in a comprehensive way direction of development of the Polish Armed Forces. Its implementation, however, will require a lot of effort not only from the military, civilian political leadership, but also from the entire state. It assumes firstly an increase in spending on defense, secondly, the introduction of a reform of the command system of the Polish Armed Forces, and finally the introduction of a number of structural changes in the Polish Armed Forces. This is not only about forming a new, additional division, but also (and perhaps above all) strengthening existing structures, with, among others, logistics, reconnaissance and engineering units. Therefore, the armed forces will have to face the necessity of simultaneous forming of new units. How will this relate to the operational rivalry between the different types of troops? This is a big challenge in terms of logistics and organization, it will require coordination of undertaken activities.

\section{The Process of Modernization of the Armed Forces: A Myth or Reality?}

By definition, modernization of the contemporary Armed Forces of the Republic of Poland, at least in a limited way, should meet RMA. In no way can we meet it in a holistic way, which results not only from long-term negligence. We should be aware with all openness that the Polish state does not need it in the American version (Cohen, 2009, pp. 157-166). However, we cannot afford to further deepen the technological collapse of the armed forces. The 
reform of the equipment purchasing system for the Polish army seems to be indispensable. In this respect, the need to establish an Armaments Agency is provided for (Decyzja nr 23/ MON...2018). We are talking here about a strong institution that coordinates the entire process of obtaining equipment, from defining requirements and conducting analyses, to the implementation of purchase procedures, to putting equipment into operation. This is the assumption. Today there is a lack of a holistic approach and coordination, and some conditions make it difficult to implement programs or, paradoxically, introduce equipment that does not meet requirements necessary from the point of view of operational capability. As a consequence, the purchasing system is inefficient and the institutions that implement it function despite the lack of effects of their activities. Can this be changed? Purchase priorities should be determined by the military. They are by default supposed to define needs that should be in line with the rationality and professionalization of the armed forces. Meanwhile, not only do we not pay attention to our own needs, but we also create innovative concepts for the current policy that cause us to wander in dilettantism (Wiceminister MON...2017).

Despite the plans of the Ministry of National Defense and media declarations, it was not possible to sign a contract for the implementation of the first stage of the Vistula program, the Homar rocket artillery system or helicopters for Special Forces and Navy, nor was the partner for the Orka submarine program selected. Information that the USA is ready to sell Patriot batteries has appeared in the media space, but the final effect of this action cannot be predicted (Świerczyński, 2018, p. 7). It should be emphasized here that these batteries condition the implementation of the already delayed Vistula system. The current implementation of the Homar project looks no better. The current minister shocks with propaganda declarations (Maciarewicz: Polska...2017). Meanwhile, I believe that public opinion will continue to be flooded only with fantasies. Is it not time for modernization projects to come out of the ... utopia phase? In addition, next year agreements should be signed for, e.g., Orlik unmanned aerial vehicles or the Rosomak BMS system, the integration of these transporters with Spike missiles, or finally Mustang off-road vehicles, planned earlier for signing in 2017 and significant for the operational troops potential (Nowy przetarg na samochody...2017). It is also urgent to solve problems that arise around the Narew, Orka, or even the Kruk attack helicopter programs, as well as those for the implementation of anti-tank weapons purchase projects recently included in the Technical Modernization Plan. Given the dynamics of the modernization process and the possibility of delays, it is not possible to say with certainty which of these programs will be finalized (Modernizacja Sił Zbrojnych RP...2017). The armaments policy, so important from the point of view of this "self-sufficiency", was brought to accusations of lobbying, corruption and fraud. Not only do we create "abstract" visions of needs for the current policy, but we also offend our partners and those who are still our allies. There is also another picture related to the activity of Polish armaments plants. As reported by one of the government's favorable weekly magazines, a business and social arrangement to siphon public money with the help of apparent contracts, fictitious trainings and inflated invoices was created around one of 
the largest state-owned companies. According to journalists, connections of a "doubtful" business nature concern even the level of the management of Polska Grupa Zbrojeniowa (Polish Armaments Group) and the political cabinet of the Ministry of National Defence (Pyza, Wikło, 2018, pp. 20-28).

\section{Will the Polish Arms Industry Be Up to the Task?}

An interesting concept. Polish arms industry, strong and competitive on global arms markets, dynamically cooperating with a modern army. The consolidation of the Polish arms industry makes many happy. As a result of the consolidation of the Polish defense industry, Grupa kapitałowa PGZ SA (Polish Armaments Group), under the control of the State Treasury, employs approximately 17,000 employees and covers a wide range of production companies - from armored and maritime equipment manufacturers, to modern technologies, to ammunition. So much for statistics, which, propaganda-supported, fill many with pride.

However, was it possible to overcome all the difficulties affecting the ability to absorb the modernization of the Polish Army? There are several serious difficulties. Let us try to point them out, stressing that they all interact with each other. The sequence in which they are indicated in this case is only ordinal. The first, important from the point of view of the ability to "respond" to the demand for modernization of the armed forces, is the politicization that limits the decision-making processes both in the boards of the Polish arms industry and in the defense department. It seems that it significantly limits the rational view of the product and ultimately the support for the production, purchase and use of weapons. Polish arms companies must be able to participate to tenders with competitive bids. Their only asset cannot be the "Polishness" of the product. It must be remembered that this is a dubious argument when the majority of tenders for equipment for the army are carried out on the basis of the provisions of the Public Procurement Law, in the mode provided for defense orders. Offers are subject to substantive evaluation, and the best one should be chosen. When spending public money, the defense department should consequently act in accordance with the principles of public finances. It is not admissible to "advance" a product (MON zamyka rok rzutem...2017). The second difficulty is the ability of the Polish arms industry to cooperate in terms of manufacturing the target product. It seems that modern economic mechanisms must be ready to acquire modern technologies, regardless of economic constraints. The search for a "purely Polish" product in the field of military technology is a utopia. Nowadays, it is not possible to build a complicated warfare agent based on one's own capabilities. Using the opportunities offered by participation in international programs ensures access to modern technologies. Often, it also creates greater financial opportunities, which means that participation in the development of large, complex, innovative technologies does not require production of such large financial resources as carrying out the work on one's own. It seems to be a truism, though not as obvious as one would expect 
(Innowacyjne projekty...2015). Another difficulty arises from doubts as to how the defense industry (consolidated or not) is able to meet the ambitious, sometimes necessary, plans for technical modernization of the Polish Armed Forces. It often seems that companies from this industry, both in terms of management and the product addressed to the armed forces, stay in the deep war economy of the socialist period. Armaments plants are demanding multi-million orders for their products. It seems that not only the limitation of costs of modernization is not fully understood. However, not only that. It gets forgotten that modern enterprises, even armaments ones, must be adapted to the requirements of modern global economy. The development of enterprises' abilities, including readiness to act as an offset recipient, lies with the managers of individual industrial entities. Many foreign armaments companies easily cope both in a good economic situation for military products and in lack thereof. In Boeing (the third armaments company in the world according to the report of the Stockholm International Peace Research Institute) only 30 percent of production is production for the needs of the army. In Airbus, in the seventh place, it is at 17\% (Polska zbrojeniówka... 2017).

\section{Conclusions}

The Polish Army, being one of the constitutive institutions of the state, is determined by the system of state power. In spite of their being non-party bound and political neutrality, the military remain under the influence of political forces. Widely understood military security is one of the main areas of Polish policy. Poland's present ruling team has greatly expanded its influence on the armed forces, giving great importance to security policy. By definition, the Polish Army is to be one of the determinants of Poland's strength and position in the international environment. Unfortunately, according to the author, by assigning such significance to this state institution, the rulers react to a small extent to changes affecting the modern armed forces. The author presents those resulting from the diagnosis of the revolution in military matters. These issues, to a small extent, despite the great importance given to military cooperation with the USA, are not properly treated. The paper signals a number of threats that should be noticed through the above-mentioned issues. According to the author, in the Polish security policy, the ability to react to them can be seen in a real, non-propaganda way to a small extent. The decision-makers respond to the challenges for Poland's security policy also to a small extent. The author includes among others modernization of the armed forces in those that to the largest extent can decide on its effectiveness. Essentially, it depends on various factors. Undoubtedly, the strongest factor for the modernization of the Polish Army is the political one. The author proves in the paper that despite the plans of the Ministry of National Defense and media declarations, the modernization process is ineffective. Although since 2016 all funds from the modernization fund have been spent twice in a row, no important program for the modernization of the Armed Forces has been implemented. Contracts in all major weapons programs: Wista, 
Homar, Orka, Kruk or helicopters failed to be signed. The author also wonders about the impact of the ineffective Polish defense industry. Managers of Polish armaments plants often emphasize its possibilities. According to Polish producers, their products are of very high quality and can meet the requirements of not only Polish armed forces. Nevertheless, the Polish Army does not receive proper modernization support.

\section{References}

„Czaputowicz: Szczyt NATO w Brukseli sygnałem o spójności sojuszu” (2018, February 9). Defence24. pl. Downloaded from: http://www.defence24.pl/czaputowicz-szczyt-nato-w-brukseli-sygnalem-ospojnosci-sojuszu

„Macierewicz w Kanadzie tłumaczył, dlaczego Polska musi być gotowa na wojnę z Rosją” (2017, November 19). Gazeta.pl. Downloaded from: http://wiadomosci.gazeta.pl/wiadomosci/7,114884,22665329,mac ierewicz-w-kanadzie-ostrzega-przed-wybuchem-wojny.html.

„Modernizacja Sił Zbrojnych RP: Kluczowe umowy przechodzą na 2018 rok” (2017, December 29). Defence24pl. Downloaded from: http://www.defence24.pl/719997,modernizacja-sil-zbrojnych-rpkluczowe-umowy-przechodza-na-2018-rok-podsumowanie.

„MON zamyka rok rzutem na taśmę. Umowy na trzy nowe okręty” (2017, December 27).tvn24.pl. Downloaded from: https://www.tvn24.pl/wiadomosci-z-kraju,3/modernizacja-wojska-umowy-na-okretykormoran-i-ratownik,801697.html

„Możliwości militarne Wojska Polskiego. Jak wyglądamy na tle Europy?”(2017, August 14). Onet.pl. Downloaded from: https://wiadomosci.onet.pl/tylko-w-onecie/wojsko-polskie-liczebnosc-i-uzbrojenieinfografika/e77zjgr

„Najnowszy pomysł Zbigniewa Gryglasa. „Husaria” na quadach” (2018, May 3). Wirtualna Polska. Downloaded from https://wiadomosci.wp.pl/najnowszy-pomysl-zbigniewa-gryglasa-husaria-naquadach-6247820698732161

„Strategia Bezpieczeństwa Narodowego Rzeczypospolitej Polskiej z 5 listopada 2014 roku” (2014 December 11). BBN. Downloaded from: https://www.bbn.gov.pl/ftp/SBN\%20RP.pdf

„Strategia Polskiej Polityki Zagranicznej 2017-2021” (2017) MSZ. Downloaded from: https://www.msz. gov.pl/resource/978285e3-5684-4fcb-8d7e-d0a8bfdb0fdb:JCR

"Wiceminister MON:, śmigłowce mają dla armii dziesięciorzędne znaczenie”. Eksperci twierdzą co innego" (2017, March 28). TVN24pl. Downloaded from: fakty.tvn24.pl/ogladaj-online,60/bartosz-kownackismiglowce-maja-dla-armii-dziesieciorzedne-znaczenie,727411.html

„Współpraca obronna: Rada przyjmuje plan wdrażania PESCO” (2018, March 6). Rada EU. Downloaded from: http://www.consilium.europa.eu/pl/press/press-releases/2018/03/06/defence-cooperationcouncil-adopts-an-implementation-roadmap-for-the-permanent-structured-cooperation-pesco/

Balcerowicz, B. (1999). Sojusz a obrona narodowa, Warsaw: Wydawnictwo Bellona.

Blaker, J. (1997). Understanding the Revolution in Military Affairs: A Guide to America's $21^{\text {st }}$ Century Defense, Washington, DC: Progressive Policy Institute.

Cohen E. (2009). Wojna i technologie. In: J. Baylis, J. Wirtz, C.S. Gray, E. Cohen (eds.) Strategia we wspótczesnym świecie. Wprowadzenie do studiów strategicznych. Kraków: Wydawnictwo Uniwersytetu Jagiellońskiego. 
Colin, G. (2004). Strategy for Chaos: Revolutions in Military Affairs and the Evidence of History, Londyn: Routledge.

Decyzja nr 23/MON Ministra Obrony Narodowej z dnia 14 marca 2018 r. w sprawie powołania Pełnomocnika Ministra Obrony Narodowej do spraw utworzenia Agencji Uzbrojenia. (2018, March 14).Dziennik Urzędowy Ministra Obrony Narodowej. Downloaded from: http://www.dz.urz.mon.gov. $\mathrm{pl} /$ dziennik/pozycja/decyzja-27-dedcyzja-nr-23mon-z-dnia-14-marca-2018-r-w-sprawie-powolaniapelnomocnika-ministra-obrony-narodowejdo-spraw-utworzenia-agencji-uzbrojenia/

Dochody budżetowe resortu obrony narodowej na 2014 rok, załączniki do decyzji nr 29/MON z dn.12.02.2014 (Dz. Urz. MON poz. 45) p.111.

Doughty, A.R. (2001). The Evolution of US Army Tactical Doctrine, 1946-76, Darby, Pennsylvania: DIANE Publishing.

Leksykon Bezpieczeństwa Wewnętrznego. (2017). W. Fechler, J. Piątek, R. Podgórzańska (eds.). Szczecin: wydawnictwo naukowe Wydziału Humanistycznego US MINERWA.

Mrówka P. „Twierdzą będzie każdy próg” czyli o Obronie Terytorialnej (2017, August 14). Teologia Polityczna. Downloaded from: https://teologiapolityczna.pl/przemyslaw-mrowka-twierdza-nam-bedzie-kazdyprog-czyli-o-obronie-terytorialnej

Paszyn M., Kordowski M., Zalewski W. (2016), Koncepcja obrony terytorialnej w Polsce, Warsaw: Narodowe Centrum Studiów Strategicznych.

Piątek, J. (2011). Rewolucja w dziedzinie wojskowości. In: Encyklopedia zagadnień międzynarodowych, E. Cała-Wacinkiewicz, R. Podgórzańska, D. Wacinkiewicz (eds.), Warsaw: wydawnictwo C.H. Beck.

Piątek, J. (2012). Międzynarodowe stosunki wojskowe i podstawy rozumienia strategii. In: J. Piątek, R. Podgórzańska, A. Ranke, Polityka zagraniczna i strategie bezpieczeństwa państw w międzynarodowych stosunkach politycznych, Gorzów Wielkopolski: Wydawnictwo Naukowe Państwowej Wyższej.

Świerczyński, M. (2018). «Jak negocjujemy zakup Patriotów?» Polityka Insight Raport Zbrojeniowy styczeń. Zięba, R. (2007). Paradoksy polityki zagranicznej Polski w okresie transformacji. In: M. Karwat (ed.) Paradoksy polityki. Warsaw: Wydawnictwo Elipsa.

Pyza, M., Wikło. M. (2018). „Pilnowanie Dobrej Zmiany”. Sieci, 19, pp. 20-28.

Zięba, R. (2011). Polska polityka bezpieczeństwa między atlantyzmem i europeizmem. Downloaded from: http://www.uclm.es/lamusa/ver_articulo.asp?articulo=147\&lengua=pl

„Innowacyjne projekty PGZ za pieniądze z Unii” (2015, May 14). PGZ Polska Grupa Zbrojeniowa. Downloaded from: http://pgzsa.pl/a/87,innowacyjne-projekty-pgz-za-pieniadze-z-unii

„Polska Grupa Zbrojeniowa potęgą!” (2016, December 18). Fakt.pl. Downloaded from: www.fakt.pl/facet/ militaria/polska-grupa-zbrojeniowa-na-60-miejscu-na-swiecie/031sjnz.

"Struktura i zadania" (2016, December 28). MON. Downloaded from: http://www.mon.gov.pl/obronaterytorialna/pytania-i-odpowiedzi/struktura-i-zadania-j2016-12-28/

Baltic Air Policing (2017, April 27). MON. Downloaded from: http://www.mon.gov.pl/sily-zbrojne/misjezakonczone/baltic-air-policing-u2017-04-27/

„Dzień otwarty bazy antyrakietowej w Redzikowie” (2017, July 3). Defence24pl. Downloaded from: http:// www.defence24.pl/622051,dzien-otwarty-bazy-antyrakietowej-w-redzikowie.

„Macierewicz: Polska kupi 160 wyrzutni Homar” (2017, July 11). Defence24pl. Downloaded from: http:// www.defence24.pl/626952,macierewicz-polska-kupi-160-wyrzutni-homar.

„Nowy przetarg na samochody terenowe Mustang” (2017, July 18). DziennikZbrojny.pl. Downloaded from: http://dziennikzbrojny.pl/aktualnosci/news,1,10605,aktualnosci-z-polski,nowy-przetarg-nasamochody-terenowe-mustang. 
„Polska zbrojeniówka spada w rankingu” (2017, December 11). Rzeczpospolita. Przemyśl obronny. Downloaded from: http://www.rp.pl/Przemysl-Obronny/171219836-Polska-zbrojeniowka-spadaw-rankingu.html

\section{Author}

\section{Prof. dr hab. Jarosław Piątek}

University of Szczecin, Institute of Political Science and European Studies. Contact details: ul. Krakowska 71-79, 71-017 Szczecin, Poland; e-mail: tankpanc@wp.pl 